\title{
Collaborative governance model in COVID-19 pandemic mitigation: a temporary unconditional cash transfer program
}

\author{
I Gede Eko Putra Sri Sentanu ${ }^{I^{*}}$, Klara Kumalasari ${ }^{1}$, and Ardian Prabowo ${ }^{1}$ \\ ${ }^{1}$ Public Administration, University of Brawijaya, Indonesia
}

\begin{abstract}
The COVID-19 disaster has spread all over Indonesia, causing a sense of laziness for people in the economy by paying very large costs, limited activities, and even losing their jobs. The government through the direct cash assistance program as a mitigation measure in reducing the impact of the COVID-19 pandemic, but so far it has not been effective. The purpose of this study was to determine the ideal cooperative governance model for the cash transfer program during the COVID-19 pandemic. This study uses a qualitative method with a descriptive approach. The results of this study indicate that the cash transfer program still has many obstacles in distributing it to many people who are not on target, which is the result of collaboration between stakeholders such as the Social Service, Population and Civil Registry Office, Village Government, Village Community, Coordinator Team Field, and the COVID-19 Task Force Team. To increase cooperation between these stakeholders by strengthening on several sides such as: First, the government conducts data collection and systematic data collection between the recommendations of the names of beneficiaries from the village with the approval by the Population and Civil Registry Office and the Social Service Office. Second, the Government and the Community carry out monitoring and supervision. The desired impact is that the temporary unconditional cash transfer program can run effectively and benefit people in need. This program is a social network during the COVID-19 period.
\end{abstract}

\section{Introduction}

Currently, the outbreak of the COVID-19 infectious disease can spread rapidly throughout the world [1], including Indonesia [2,3]. In addition to having an impact on the health sector, this pandemic has an impact on the economy. In the macroeconomy, the world economy lost + US\$ 1 trillion and world economic growth was below $2 \%$, far below the previous prediction of $2.5 \%$ [4]. As for the micro economy, the pandemic has had an impact on traders, especially since the call for restrictions on mobility. Shopping centers are limited in the number of visitors, so sellers have started to complain that their sales have dropped since the COVID-19 case. This impact also threatens workers or employees affected by the termination of employment (PHK) as a result of the heavy workload and reduced financial liquidity of the company [5]. Some of these problems have an impact on the decline in people's purchasing power in line with the low inflation rate [

According to the Social Health Insurance Administration Body (Badan Penyelenggara Jaminan Sosial Kesehatan/ BPJS), there were 2.1 million layoffs in Indonesia in 2020, while according to the Ministry of Manpower, there were 3.5 million formal and informal workers affected by COVID-19 [7]. One of the main sectors affected is tourism. The increasing number of layoffs in the tourism sector worsens the situation of an area. Batu City, a city that relies on the tourism sector, has felt the impact of the COVID-19 Pandemic. According to the Batu City Government, the tourism sector almost accounts for $40 \%$ of the total Original Local Government Revenue (OLGR) of Batu City [8]. The following are the numbers of employees who work at home and employees on layoff in Batu City as follows:

Table 1. Number of Employment Termination in the Malang area

\begin{tabular}{|c|c|c|c|}
\hline \multirow{2}{*}{ No } & \multirow{2}{*}{ City } & \multicolumn{2}{|c|}{ Total Pegawai } \\
\cline { 3 - 4 } & & $\begin{array}{c}\text { Employees } \\
\text { On Layoff }\end{array}$ & $\begin{array}{c}\text { Employees at } \\
\text { home }\end{array}$ \\
\hline 1. & $\begin{array}{c}\text { Malang } \\
\text { City }\end{array}$ & 162 & 1.465 \\
\hline 2. & $\begin{array}{c}\text { Malang } \\
\text { Regency }\end{array}$ & 2.359 & 247 \\
\hline 3. & $\begin{array}{c}\text { Batu } \\
\text { City }\end{array}$ & 52 & 2.555 \\
\hline
\end{tabular}

From these problems, government efforts need to be made in mitigating social networking from the COVID19 pandemic disaster to overcome the economic problems felt by the community. One of the government programs for social networking by providing social assistance to people affected by COVID-19. The social assistance policy for people affected by COVID-19 is the government's response to the COVID-19 pandemic,

* Corresponding author: sentanu@ub.ac.id 
especially for people who have decreased income or even lost their jobs [9]. However, in the process, there are still some problems in its distribution $[10,11,12]$. In the distribution of direct cash social assistance, there are several obstacles to the implementation of the policy. Several problems occurred during the COVID-19 pandemic, including the distribution of social assistance. the central and local governments, have several obstacles in distributing social assistance to the community [10]. The social assistance policy is still not effective, there are still many obstacles that must be resolved by the government. Therefore, the government needs to make improvements in the distribution of target recipients.

Collaborative governance theory is an important issue in the relationship between local governments and village governments, communities, and businesses. Collaborative Governance is one way to respond to the wishes of stakeholders to be involved in the implementation of development and to respond to the limited government funding that cannot keep up with the development of community demands for better government performance to obtain resources to carry out development according to the expectations of these stakeholders $[13,14]$. In a pandemic emergency, it is not only the government's responsibility but also contributions from other stakeholders are needed through deliberation in forums, building understanding and commitment, and a sense of responsibility to immediately end this pandemic $[15,16]$.

\section{Experimental Method}

This study uses a qualitative descriptive approach. Descriptive research is research that provides a clear and systematic description of the object under study. This research also provides information and data following the phenomena in the field. The method used in this study uses qualitative research methods. According to Creswell [17], qualitative research is a method to explore and understand the meaning that some individuals or groups of people ascribe to social or humanitarian problems. This qualitative research process involves important efforts, such as asking questions and procedures, collecting specific data from participants, analyzing data inductively from specific themes to general themes, and interpreting the meaning of the data.

The location of this research is in Batu City, East Java. This research is sourced from primary data and secondary data, namely by data collection techniques consisting of interviews, observations, and documentation. This research consisted of one key informant, namely Deny Sumatra as an employee of the Social Service Secretariat of Batu City. Key informants should be people who are willing to share concepts and knowledge with researchers and are often used as a place to ask questions by researchers. For this reason, in collecting data, researchers should start from the key informants to get a complete and comprehensive picture of the problems observed [18]. The interview method in this study is a semi-structured interview. The interview starts from the issues covered in the interview guide, then the researcher can develop questions and decide how the issues are raised [19].

\section{Result and Discussion}

\subsection{Factors}

\subsubsection{Starting Condition}

Starting Condition is the initial condition when Collaborative Governance is implemented. The initial stages include the historical conditions of cooperation in the past, potential, and incentives expected from the Collaborative Governance process. Since the beginning of the establishment of social assistance policies for communities whose economies have been affected by COVID-19, the Social Service has actively collaborated with several actors who are considered competent in their fields, such as activities from planning to evaluation. Cooperation is also carried out during the implementation of the policy. However, in the implementation of the social assistance policy, there are several obstacles. It is explained by Sumatra, as follows:

"Kalau dalam pelaksanaan kebijakan bantuan sosial tersebut tentu ada kendala paling sering adalah kendala teknis". (In the implementation of the social assistance policy, of course there are obstacles, most often technical problems). Interview results on January 20, 2021.

The existence of these obstacles stems from technical constraints, for example, the distribution of social assistance is still incomplete, causing double data problems for prospective recipients of social assistance.

\subsubsection{Institutional Design}

Institutional Design is a cooperation forum attended by members, has clear rules, and is an open process. In the policy of distributing COVID-19 social assistance in Batu City, the social service has several times held focus group discussions with the actors involved in the policy. The focus group discussion is held once a month to discuss technical guidelines related to the distribution of social assistance and evaluation. This is explained by Sumatra, as follows:

"Dinas Sosial di Kota Batu melaksanaan beberapa kali FGD dengan tujuan seperti memusyahwarakan kendala-kendala pada kebijakan penyaluran bantuan sosial, dalam FGD yang kami ikutkan adalah aktor-aktor yang terlibat pada kebijakan itu misalnya Dinas Sosial, Dinas Kependudukan dan Catatan Sipil, Pemerintah Desa, Masyarakat Desa, Tim Koordinator Lapangan, dan Tim Satgas COVID-19”. (The Social Office in Batu City held several FGDs with the aim of discussing the constraints on the policy of distributing social assistance, in the FGDs that we included were the actors involved in the policy, for example the Social Service, Population and Civil Registry Office, Village Government, Community Village, Field Coordinator Team, and COVID-19 Task Force). Interview results on January 20, 2021.

The social service in building this forum involves several actors who participate even though they have not been maximized in the forum. Every time a forum is held, the Batu City Social Service forms a closed committee, usually, the committee consists of employees from the Batu City Social Service. 


\subsubsection{Facilitative Leadership}

Facilitative Leadership relates to deliberation by actors, setting clear ground rules, building trust, facilitating dialogue between stakeholders, and sharing mutual benefits. The social assistance policy for the COVID-19 community under the leadership of the head of the Batu City social service Ririk Mashuri, S.St, Mm, the head of the social service has a major influence on the COVID-19 social assistance policy for the economy of the community affected by COVID-19. In addition, the Head of the City Service is a leader who has charisma. The head of the Batu city social service has charisma in his leadership such as a competent educational background according to his field. This statement is supported by the statement of Sumatra, as follows:

"Kita sanggat terbantu dengan kepala dinas sosial yang menjabat sekarang dikarenakan latar belakang pendidikan nya sesuai dengan bidang dinas sosial sehingga sumbangsih ilmu diberikan kepada staffnya". (We are greatly helped by the current head of the social service because his educational background is in accordance with the field of social services so that knowledge contributions are given to his staff). Interview results on January 20, 2021.

\subsubsection{Collaborative Governance Process}

\subsubsection{Face to face dialog}

Face-to-face dialogue or face-to-face meeting is a meeting between various parties in the same location and time so that there is a direct or interactive dialogue between the various parties, to discuss a common interest. Direct dialogue with the Batu city social service has been well institutionalized. The form of face-to-face dialogue carried out by the Batu City social service includes meetings. These meetings are like focus group discussions. These meetings can be attended by all actors involved. However, the FGD was deliberation and consensus. This was conveyed by Sumatra as follows:

"FGD bersifat tertutup dan terbatas. Ada rapat yang dilakukan oleh beberapa orang dengan terbatas karena beberapa hal tidak perlu dilakukan dengan banyak orang. Namun ada rapat bersifat uтum semua orang dapat berpartisipasi, biasanya sesuai pengaruh dari topik rapat tersebut". (FGDs are closed and limited. There are meetings that are held by a few people to a limited extent because some things don't need to be done with a lot of people. But there are general meetings everyone can participate, usually according to the influence of the topic of the meeting). Interview results on January 20, 2021.

\subsubsection{Trust building}

Trust building or building trust is a management strategy not only focused on now, but also for future cooperation. Building trust has the same intention to take the best policy for all parties. Trust Building begins by building communication between various actors involved in the policy of distributing COVID-19 social assistance. Building trust among actors has been carried out by the social service. Usually to keep a regular meeting at all times. In these meetings as a means of informing important matters and also given time to express their opinions in the next session. Disclosure of this information is key to building trust.

\subsubsection{Commitment to Process}

Commitment to Process is a commitment or agreement to carry out a certain process to achieve the desired common goal. Mutual commitment, means They depend on each other to solve problems and solutions, that this process is common property, and are open to each other for mutual benefits. Meanwhile, Mutual understanding is knowing the rules, goals, and limits of the pursuit. This is the rule of the game for every actor involved to know. Mutual understanding is a condition that is derived from deliberation, not left to unintentional thoughts and wishful thinking. Various understandings and understandings have been sought by the Batu City Social Service in several activities. The Batu City Social Service always tries to establish communication and provide information to other actors in a reciprocal manner and ask for input. D.Intermediate outcome.

\subsubsection{Intermediate outcome}

An intermediate outcome is a temporary result of an ongoing process. The temporary results have provided benefits and strategic value. The Batu City Social Service has implemented a policy for distributing social assistance, during the 2020 COVID-19 pandemic, the Batu City Office distributed cash social assistance seven times.

\subsection{Stakeholders}

The following are the actors involved in the distribution of social assistance programs to communities affected by COVID-19 in Batu City:

\subsubsection{COVID-19 Taskforce}

Actors of the COVID-19 task force unit have the role of policymakers or technical guidelines in the distribution of social assistance programs for communities affected by COVID-19 in Batu City. Actors of the COVID-19 task force unit have a low level of interest and power. the actor of the COVID-19 task force unit only establishes a network with the social service, this causes the actor of the COVID-19 task force unit to have minimal interaction with other actors

\subsubsection{Social Office}

The social service has a very crucial role in the implementation process, the role of the social service actor is as a facilitator or provider of facilities in the continuity. From the beginning of program development to the end of program implementation, it is the responsibility of the social service office, besides that the role of the social service also includes monitoring and 
evaluation, proposing technical guidelines. This actor has a high level of importance and power. So that it can be ensured that social service actors also interact with all actors to create a strong network

\subsubsection{Village Government}

Village actors act as proposers who propose candidates for social assistance recipients to the social service, the Village Head and/or Lurah report the results of data collection coordination in their area by knowing the Camat to the Mayor through the Head of the Batu City Social Service. In addition, the village is also an intermediary between the community and the social service. Actors with high importance but low power. Village actors have a low capacity to achieve goals but can become influential by forming alliances with other actors.

\subsubsection{The head of Community Association (RT/RW)}

The Community Association (RT/RW) is a communities organization that has a role to help social services and as representatives of the community in their area. as for the role of the actor. RT/RW such as data collection on prospective recipients of social assistance. In this case, the RT/RW actor cannot provide much assistance but fully support the implementation of the program

\subsubsection{Field coordinator team}

The field coordinator team actors are part of the volunteers from the social service. The field coordinator team actor consists of several communities selected by the social service. The role of the field coordinator team actor is believed to be to assist the social service for monitoring during program implementation such as validating potential recipients of social assistance, besides that the field coordinating team actor assists the RT/RW actor if there is a problem in collecting data on potential recipients of social assistance. Actors The field coordinator team does not have strong power but supports the program

\subsubsection{Population and Civil Registry Office}

The Population and Civil Registry Office is an actor from a government institution that is involved in the distribution of social assistance programs to communities affected by COVID-19 in Batu City. The role of the civil registry office of population actors is to verify the data of prospective recipients. Data verification is carried out so that there is no double data problem for recipients of COVID-19 assistance. Actors of Population and Civil Registry Office do not have high power because they only validate data on candidates for social assistance recipients for people affected by COVID-19

\section{Discussion}

From the previous data presentation, in general, the implementation of the direct cash transfer program has involved several stakeholders but still has obstacles in several ways, such as first, the government has not carried out data collection in a centralized and systematic manner between the recommendations for the names of beneficiaries from the village government and validation by the Population and Civil Registry Office and Social Office. This can provide opportunities for less targeted recipients of the assistance. Second, monitoring or supervision is carried out by the social service and the community. The community can supervise and report to the social service if something has not been received or the community receiving assistance is not appropriate. Third, to minimize the spread of COVID-19 as a result of crowds, it is necessary to carry out restrictions by the COVID-19 Taskforce and the police.

The general problems are the lack of cooperation between the actors involved, causing the implementation of the program not to run according to the needs of the community or other non-government stakeholders. The planning process is not carried out with optimal community involvement. For this reason, efforts are needed through collaborative governance. Next is the discussion about the ideal collaborative governance model in the direct cash assistance program for people affected by the COVID-19 pandemic.

Collaborative Governance models sometimes describe the gradual development of collaboration [20]. Collaborative Governance lies within the dynamics of a system context that can include resource, policy, and legal frameworks, socio-economic and cultural characteristics, network characteristics, political dynamics and power relations, and conflict history, among other dimensions [21].

Based on some previous data and referring to the Collaborative Governance Model [20] it can be seen as follows:

In particular, pre-established networks (relationships) and institutional contexts are important because they shape opportunities and constraints, and influence the if, how, and when of collaborative governance to be opened and implemented [22, 23, 24, 25]

In facilitating collaboration among stakeholders, the researchers made the coordination flow among stakeholders in implementing the cash transfer program as follows:

In Fig. 2., the researcher divides the actors by color, where each color represents the origin of government agencies, businesses, and the community. At the initial stage, community representatives, namely the head of the Community Association (RT/RW) recorded the community of potential recipients of direct cash assistance. This data collection is based on several indicators such as not receiving assistance from the PreEmployment Card Holder, experiencing loss of livelihood (not having sufficient economic reserves to survive for the next three months), and having family members who are prone to chronic/chronic illness. After the data is obtained, the RT/RW provides the Village Government with this action so that the Village Government can validate the names of the prospective beneficiaries. Furthermore, the Village Government reports by inputting data on prospective beneficiaries of assistance to the Social Service. The Department of Social Affairs and the Department of Population and Civil Registry validate the 
data received from the Village Government. If the data is appropriate, the Social Service will coordinate with the Bank and the Field Coordinator Team to distribute assistance. In the distribution of aid distribution, it is necessary to coordinate with the Police and the COVID19 Taskforce to ensure that the distribution process runs smoothly and under the applicable COVID-19 health protocol. In the process of collecting data on prospective beneficiaries to validation of beneficiaries, it is necessary to have a centralized system that is computerized or not done manually anymore, therefore minimizing errors in the manual data collection process. In addition, centralized computerization can simplify and speed up the processing of prospective beneficiaries.

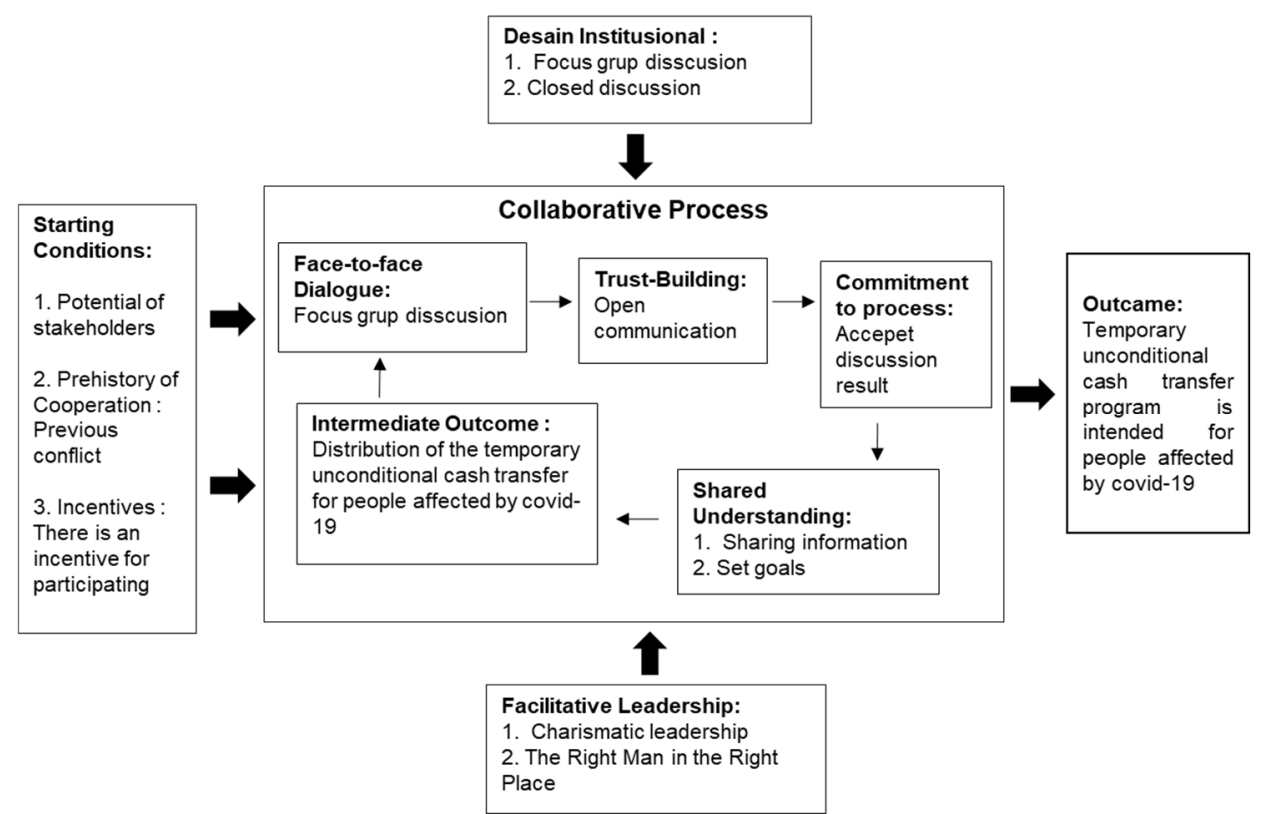

Fig. 1. Collaborative Governance in the temporary unconditional cash transfer program Source: processed by researchers, 2021

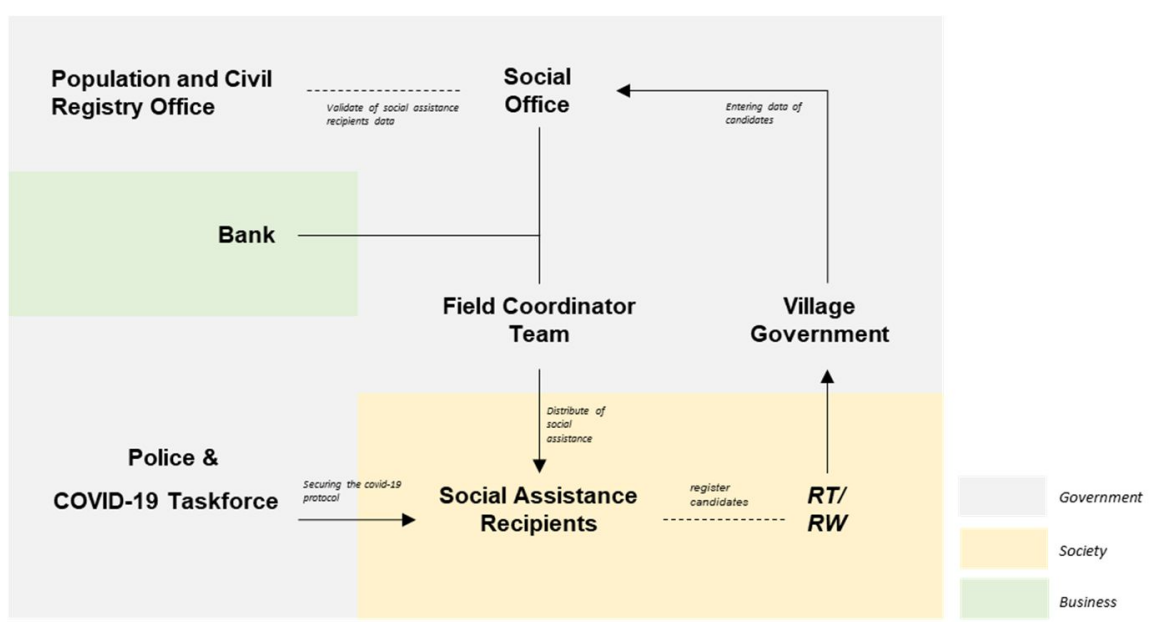

Fig. 2. Coordination Flow of the temporary unconditional cash transfer program Source: Processed by Researchers, 2021

In the process of coordination between stakeholders in the temporary unconditional cash transfer program. Researchers adopted [20] starting with the principle of collaboration which consists of facilitative leadership, setting clear ground rules, building trust, facilitating dialogue between stakeholders, and sharing mutual benefits, procedures, and basic rules in collaboration for procedural legal collaboration processes, process transparency, participant inclusivity, forum exclusivity, and accountability. In this collaboration principle, especially accountability, it is necessary to involve all stakeholders in the village. The findings of this study, the government has not involved all segmentation actors. Because the involvement of the community and the village government alone is not enough to meet the needs of rural development. So that in this model the involvement of all stakeholders is needed. According to [26] limited stakeholder involvement causes the accountability process to not run smoothly. The involvement of external or wider stakeholders must be carried out immediately to play an important role in assisting the government in carrying out its duties and functions to distribute the temporary unconditional cash transfer program as a social safety net (SSN). 


\section{Conclusions}

In the collaborative governance model, an important element of collaboration between local governments and village governments, the COVID-19 Taskforce and the Police in ensuring the process runs securing to the COVID-19 health protocol, the Bank helps facilitate the storage and provision of money to the community receiving direct cash social assistance. This study suggests that in the whole process of the direct cash transfer program by strengthening the role of local governments and village governments in conducting centralized and systematic data collection through computers to facilitate and speed up validation by the Population and Civil Registry Office and the Social Service Office. Supervision is carried out by the social service and the community. The community can supervise and report to the social service if something has not been received or the community receiving assistance is not appropriate. Furthermore, to minimize the spread of COVID-19 as a result of crowds, it is necessary to carry out restrictions made by the COVID-19 Task Force and the police. In addition, in the collaboration process, it is necessary to carry out facilitative leadership, establish clear ground rules, build trust, facilitate dialogue between stakeholders and share mutual benefits, procedures, and basic rules in collaboration for procedural legal collaboration processes, transparency of the process, inclusiveness of participants, forum exclusivity, and accountability. This process is needed at the time of cooperation to minimize problems in the field.

Thanks to Universitas Brawijaya and the Government of Batu City for facilitating this research

\section{References}

1. WHO, Report of the WHO-China Joint Mission on Coronavirus Disease 2019 (COVID-19) (2020)

2. H. P. Sari, Indonesia Called Potentially New Epicenter of COVID-19, this is the response of the government spokesman Retrieved from kompas .com on April 11 (2020)

3. L. Agustino, Analysis of COVID-19 Outbreak Handling Policy: The Experience of Indonesia, Jurnal Borneo Administrator, 16,2. (2020)

4. World Bank. Global Economic Prospects. A World Bank Group Flagship Report. 30 $0^{\text {th }}$ Anniversary edition (2021)

5. Purwanto, Agus, et al. "Impact of work from home (WFH) on Indonesian teachers performance during the COVID-19 pandemic: An exploratory study." International Journal of Advanced Science and Technology 29.5. 6235-6244 (2020)

6. M. Yuniati, R. Amini, Analysis of the Impact of COVID-19 on People's Purchasing Power NTB. MPU PROCURATIO: Management Research Journal. 2, 2. (2020)

7. Kurnia, Ade Miranti. Due to Corona, more than 3.5 million workers have been laid off and laid off. Retrieved from kompas.com on Septembre 1, 2021 (https://money.kompas.com/read/2020/08/04/16390 0726/imbas-corona-lebih-dari-3-5-juta-pekerjakena-phk-dan-dirumahkan?page=all.)

8. Fizriyani, W. Tourism Sector Becomes the Largest PAD Contributor in Batu City. Retrieved from Republika.co.id on Septembre 1, 2021. (https://www.republika.co.id/berita/qmfajs384/sekto r-wisata-jadi-penyumbang-pad-terbesar-kota-batu) (2021)

9. Darwadi MS, A. Rosihan, B. S. Utomo, Mitigation of the COVID-19 Pandemic Disaster at Ogan Komering Ulu, ETTISAL : Journal of Communication. 5,2 (2020)

10. Ihsanuddin. Presiden Jokowi Teken Keppres Determine the National Disaster COVID-19 Outbreak. Retrieved from Kompas.com on Agust 1, 2021. (https://nasional.kompas.com/read/2020 /04/13/18101841/presiden-jokowiteken-kepprestetapkan-wabah-COVID-19-bencana-nasional)

11. Dewi, Wahyu Aji Fatma. The impact of COVID-19 on the implementation of online learning in elementary schools. Educational: Journal of Educational Science 2.1, 55-61 (2020)

12. Herdiana, Dian. "Collaborative supervision in the implementation of social assistance policies affected by COVID-19." Jdp (government dynamics journal) 3.2, 85-99 (2020)

13. T.Sambodo, G, U Pribadi, U. Implementation of Collaborative Governance in the Brosot Cultural Village, Galur, Kulonprogo , DI. Yogyakarta. Journal of Governance and Public Policy, 3(1) (2016)

14. A. Prabowo, M. R. K. Muluk, A. Hayat. Collaborative Governance Model in Village Development during the COVID-19 Period: A Study in South Lampung Regency,PUBLICIA: Journal of Public Administration. 6,1 (2021)

15. S. Megawati, F. Niswah, T. A. Oktariyanda, Collaborative Governance as Handling Efforts of Pandemic COVID-19 in Surabaya City, in Proceedings of the 3rd International Conference on Social Sciences, ICSS, Atlantis Press (2020)

16. I. Wahidah, M. A. Septiadi, M. C. A. Rafqie, N. F. S. Hartono, R. Athallah, COVID-19 Pandemic: Analysis of Government and Community Planning in Various Prevention Measures, J. Manajemen dan Organisasi. 11, 3. (2020)

17. Creswell, John W., and Cheryl N. Poth. Qualitative inquiry and research design: Choosing among five approaches. Sage publications (2016)

18. Martha, Evi, and Sudarti Kresno. "Qualitative research methodology for the health sector." (2016)

19. Rachmawati, Imami Nur. "Data collection in qualitative research: interviews." Indonesian Journal of Nursing 11.1 35-40 (2007)

20. Ch, Ansell, and A. Gash. "Collaborative governance in theory and practice." Journal of Public Administration Research and Theory 18 :548-571 (2007) 
21. K. Emerson, \& T. Nabatchi, Collaborative governance regimes. Georgetown: Georgetown University Press (2015)

22. J. M. Bryson, B. C. Crosby, \& M. M. Stone, Designing and strategically managing cross-sector collaborations, John M. Bryson: The Us-India Relationship (2015)

23. J. Sandfort, \& S. Moulton, Effective implementation in practice: Integrating public policy and management, USA: John Wiley \& Sons (2014)

24. H. Dickinson, \& J. Glasby, 'Why partnership working doesn't work' pitfalls, problems, and possibilities in
English health and social care. Public Manage Rev, 12 (2010)

25. M. McGuire, \& R. Agranoff, The limitations of public management networks. Public Adm 89 (2011)

26. F. H. Zeho, A. Prabowo, R. A. Estiningtyas, Mahadiansar, \& I. G. E. P. S. Sentanu, Stakeholder collaboration to support accountability in village fund management and rural development. Journal of Socioeconomics and Development, 3(2), 89-100 (2020) 